\title{
Pengembangan Soal Aritmetika Sosial Berbasis Literasi Matematis Siswa SMP
}

\author{
Adi Asmara ${ }^{1}$, Debby Juita Sari ${ }^{2}$ \\ ${ }^{1,2}$ Program Studi Pendidikan Matematika, Fakultas Ilmu Pendidikan, Universitas Muhammadiyah Bengkulu \\ Jl. Bali, Kp. Bali, Kec. Tlk. Segara, Kota Bengkulu \\ adiasmara@umb.ac.id
}

\begin{abstract}
Mathematics Learning for students is expected not only to have the ability to count, but also to support the ability to reason logically, critically, and communicate for problem solving in everyday life. The purpose of this study was to produce valid and practical items based on mathematical literacy for seventh grade junior high school students. This research is a development's research that uses the Tessmer development model consisting of several stages, namely: preliminary, self-evaluation, expert review and one-to-one, small group, and field test. The subjects of this study were 6 seventh grade students. Technical analysis of the data in this study is qualitative analysis at the preliminary and self-evaluation stages, and quantitative analysis at the one-to-one stage. Based on the results of the research conducted, it was found that the questions developed were valid based on the assessment of the validator or at the expert review stage and the questions developed were practical based on student comments/suggestions or the results of student trials at the one-to-one stage. This development research resulted in 14 questions based on mathematical literacy level 3 on valid and practical social arithmetic material.
\end{abstract}

Keywords: Mathematical Literasi, Social Arithmetic

\begin{abstract}
Abstrak
Pembelajaran matematika bagi siswa diharapkan tidak hanya sekedar memiliki kemampuan dalam berhitung saja melainkan juga dapat menunjang kemampuan bernalar yang logis, kritis, dan berkomunikasi untuk pemecahan masalah dalam kehidupan sehari-hari. Tujuan dari penelitian ini adalah menghasilkan butir soal yang valid dan praktis berbasis literasi matematis siswa SMP kelas VII. Penelitian ini merupakan penelitian pengembangan yang menggunakan model pengembangan Tessmer terdiri dari beberapa tahapan, yaitu: preliminary, self evaluation, expert review dan one-to-one, small group, dan field test. Subjek dari penelitian ini adalah 6 orang siswa kelas VII. Teknis analisis data dalam penelitian ini yaitu dengan analisis kualitatif pada tahap preliminary dan self evaluation, dan dengan analisis kuantitatif pada tahap one-to-one. Berdasarkan hasil dari penelitian yang dilakukan, diperoleh bahwa soal-soal yang dikembangkan sudah valid berdasarkan penilaian dari validator atau pada tahap expert rewiew dan soal-soal yang dikembangkan sudah praktis berdasarkan komentar/saran siswa atau hasil uji coba siswa pada tahap one-to-one. Penelitian pengembangan ini menghasilkan 14 soal berbasis literasi matematis level 3 pada materi aritmetika sosial yang valid dan praktis.
\end{abstract}

Kata kunci: Literasi Matematis, Aritmetika Sosial

Copyright (c) 2021 Adi Asmara, Debby Juita Sari

Corresponding author: Adi Asmara

Email Address: adiasmara@umb.ac.id (Jl. Bali, Kp. Bali, Kec. Tlk. Segara, Kota Bengkulu)

Received 10 August 2021, Accepted 09 September 2021, Published 11 September 2021

\section{PENDAHULUAN}

Pembelajaran adalah usaha sadar pendidik untuk membantu peserta didik agar dapat belajar sesuai dengan kebutuhan dan minatnya (Arfani, 2016). Pembelajaran matematika adalah proses yang dirancang dengan tujuan untuk menciptakan suasana lingkungan yang memungkinkan seseorang melaksanakan kegiatan belajar matematika, dan proses tersebut berpusat pada mengajar matematika dengan melibatkan partisipasi aktif siswa di dalamnya (Hamzah \& Muhlisrarini, 2014:65). Pembelajaran matematika di sekolah idealnya harus dapat membekali siswa dengan kemampuan dan keterampilan untuk menghadapi permasalahan dalam kehidupan sehari-hari (Ramadianti et al., 2018). Penguasaan matematika yang baik dapat membantu menyelesaikan masalah tersebut (Johar, 2012). 
Tujuan pelajaran matematika di SMP adalah agar siswa mempunyai kemampuan matematis yaitu kemampuan pemahaman konsep, kemampuan pemecahan masalah, kemampuan berpikir kreatif, kemampuan berpikir kritis, kemampuan penalaran, dan kemampuan komunikasi dalam matematika. Hal ini sesuai dengan isi yang tercantum dari Permendikbud No.58 Tahun 2014 tentang karakteristik matematika (Kemendikbud, 2014). Dengan dipelajarinya matematika, para siswa diharapkan untuk tidak hanya sekedar memiliki kemampuan dalam berhitung saja tetapi dapat menunjang kemampuan bernalar yang logis, kritis dan berkomunikasi untuk pemecahkan masalah dalam kehidupan sehari-hari. Kemampuan matematis yang demikian dikenal sebagai kemampuan literasi matematis.

Literasi matematis dapat diartikan sebagai kemampuan memahami dan menggunakan matematika dalam berbagai konteks untuk memecahkan masalah, serta mampu menjelaskan kepada orang lain bagaimana menggunakan matematika (Abidin et al., 2018:99). Kemampuan literasi matematis diartikan sebagai kemampuan seseorang untuk merumuskan, menerapkan, dan menafsirkan matematika dalam berbagai konsep,prosedur, dan fakta untuk menggambarkan, menjelaskan atau memperkirakan fenomena/kejadian. Salah satu program yang menilai kemampuan literasi matematis adalah Programme for International Student Assessment (PISA).

Pada PISA 2018, Indonesia mendapatkan peringkat ke 73 dari 79 dengan skor 379 dari rata-rata skor OECD yaitu 500 di bidang matematika. Berdasarkan hasil PISA tersebut, bahwa peringkat Indonesia termasuk ke dalam 10 besar terbawah, sehingga Pada kenyataannya kemampuan literasi matematis siswa di Indonesia masih tergolong rendah. Memiliki kemampuan literasi matematis yang baik akan memudahkan siswa dalam menyelesaikan masalah matematika. Hal ini menuntun seseorang untuk memahami peran atau kegunaan matematika dalam kehidupan sehari-hari dan sekaligus membuat penilaian yang baik terhadap pengambilan keputusan yang tepat atas berbagai permasalahan/fenomena yang terjadi (OECD, 2019). Hal ini sejalan dengan (Maryanti, 2012) bahwa siswa belum mampu menginterpretasikan kemampuan matematis dalam kehidupan sehari-hari di berbagai konteks.

Berdasarkan hasil observasi peneliti pada salah satu Sekolah Menengah Pertama (SMP) di Kota Bengkulu, kebanyakan siswa kurang terbiasa menyelesaikan soal yang tidak sama dengan prosedur yang dipelajari. Apabila siswa diberikan soal dengan pola yang berbeda dari contoh yang diajarkan, maka siswa akan merasa mengalami kesulitan. Hal ini sesuai dengan (Wibowo et al., 2019) berkaitan dengan pengukuran kemampuan literasi matematis, soal-soal yang digunakan guru pada proses evaluasi hasil belajar siswa belum sesuai dengan indikator pada setiap level literasi matematis, karena soal yang diberikan tersebut hanya menguji pengetahuan prosedural siswa dalam menggunakan rumus matematika dan belum mampu mengasah kemampuan berpikir matematika siswa.

Dengan demikian, untuk melihat kemampuan literasi matematis siswa dalam kehidupan seharihari dan berkaitan langsung dengan aktivitas manusia, penelitian ini menggunakan materi aritmetika sosial. Sejalan dengan (Astuti et al., 2018) bahwa guru perlu melatih kemampuan literasi matematis setiap siswa dalam menyelesaikan masalah matematika. Hal ini menunjukkan bahwa diperlukan pengembangan soal-soal kemampuan literasi matematis yang valid dan praktis sebagai referensi soal- 
soal berbasis kemampuan literasi matematis. Siswa dapat melatih kemampuan literasi matematisnya dengan berlatih mengerjakan soal-soal yang terdapat indikator kemampuan literasi matematis di dalamnya.

\section{METODE}

Penelitian ini dilakukan kepada siswa kelas VII SMP yang ada di lingkungan sekitar rumah peneliti di Kota Bengkulu. Jenis penelitian ini adalah penelitian pengembangan atau Development Reseach. Metode penelitian ini menggunakan model pengembangan Tessmer 1993 yang diadopsi oleh (Zulkardi, 2006) . Tahapan model pengembangan ini meliputi tahap preliminary, self evaluation, expert review, One-to-one, dan small group.

Pada tahap preliminary, peneliti melakukan analisis kurikulum terkait materi di kelas VII sesuai dengan kurikulum 2013, analisis materi aritmetika sosial, analisis siswa, dan analisis soal kemampuan literasi matematis level 3. Selanjutnya peneliti mendesain soal-soal sesuai dengan materi dan indikator kemapuan literasi matematis level 3 yang akan dikembangkan.

Pada proses selanjutnya peneliti melakukan tahap self evaluation terhadap soal-soal yang telah dikembangkan. Hasil dari tahap self evaluation ini disebut prototype I. Selanjutnya pada tahap expert review, berdasarkan self evaluation hasil dari prototype I yang telah di desain diberikan kepada validator untuk divalidasi. Validator diminta memvalidasi secara kualitatif berdasarkan konten, konstruk, dan bahasa dari soal-soal yang dikembangkan. Komentar/saran dari validator digunakan sebagai bahan untuk merevisi prototype I. Hasil revisi protoype I yang telah valid disebut prototype II. Adapun fokus prototype yaitu:

Tabel 1 Karakteristik yang Menjadi Fokus Prototype

\begin{tabular}{|l|l|}
\hline Konten & \multicolumn{2}{|l|}{ Soal-soal untuk kemampuan literasi matematis harus sesuai dengan : } \\
& $>$ Indikator kemampuan literasi matematis level 3 \\
& $>$ Soal sesuai dengan materi (aritmetika social) \\
& $>$ Soal sesuai dengan tujuan pembelajaran \\
\hline \multirow{3}{*}{ Konstruk } & $>$ Soal memuat konsep-konsep matematika untuk kemampuan \\
& $>$ Gambar, grafik, atau sejenisnya disajikan dengan jelas dan \\
& $>$ terbaca \\
& $>$ Soal sesuai dengan level siswa kelas VII SMP \\
\hline Bahasa & $>$ Sesuai dengan EYD \\
& $>$ Penggunaan kata yang mudah dipahami (baku/umum) \\
& $>$ Soal tidak mengandung penafsiran ganda \\
\hline
\end{tabular}

Tahap selanjutnya ialah tahap one-to-one. Pada tahap ini prototype II diujicobakan kepada 6 orang siswa untuk memberikan komentar/saran dan mengisi angket terhadap soal. Fokus yang ingin diketahui pada tahap one-to-one adalah uji keterbacaan atau kepraktisan soal terhadap siswa. Hasil dari komentar siswa digunakan untuk pertimbangan keterbacaan soal yang telah dibuat. Hasil final yang 
diperoleh dari expert review dan one-to-one dalam penelitian ini adalah prototype II. untuk tahap selanjutnya yaitu small group dan field test (uji lapangan) tidak dilakukan.

Teknik pengumpulan data yang digunakan dala penelitian ini adalah: 1) metode pengumpulan data, yaitu wawancara. Wawancara dilakukan pada tahap one-to-one untuk mengetahui tanggapan siswa terhadap keterbacaan dari soal yang diberikan. 2) instrument pengumpulan data, yaitu dokumen, lembar validasi, dan lembar angket respon siswa. Dokumen yang dimaksud adalah dokumen tentang kurikulum, materi, dan soal-soal kemampuan lierasi matematis level 3.

Teknik analisis data yang digunakan pada penelitian ini adalah analisis kualitatif dan kuantitatif, sebagai berikut:

\section{Expert review}

Pada tahap ini komentar dan saran dari pakar dianalisis secara deskriptif kualitatif dan digunakan sebagai bahan untuk merevisi prototype. Revisi ini berupa komentar dan saran dari pakar terhadap kalimat-kalimat yang belum tepat agar dapat dilakukan perbaikan. Revisi pada prototype dilakukan hingga memperoleh prototype yang valid.

\section{One-to-one}

Hasil revisi dari expert review dan one-to-one terhadap prototype I kemudian disebut prototype II. Hasil pekerjaan siswa dianalisis secara kualitatif dan kuantitatif sebagai bahan masukan untuk merevisi. Analisis secara kualitatif yaitu dengan memberikan soal kepada siswa untuk melihat keterbacaan soal dengan cara mewawancarai siswa. Sedangkan analisis kuantitatif dilakukan dengan memberikan lembar respon atau lembar kepraktisan untuk mengukur keprakisan (keterbacaan) siswa terhadap soal dengan cara menghitung nilai rata-rata hasil pengisian lembar kepraktisan (keterbacaan) soal dengan rumus sebagai berikut:

$$
\bar{M}_{p}=\frac{\sum_{i=1}^{n} \bar{P}_{i}}{n}
$$

Sumber : (Dewi et al., 2019)

Keterangan :

$\bar{M}_{p} \quad$ = Rata-rata Kepraktisan Produk

$\bar{P}_{i} \quad=$ Skor Rata-rata Kepraktisan Siswa ke-i

$\mathrm{n} \quad=$ Banyak Aspek yang dinilai

Setelah dihitung rata-rata hasil penilaian lembar kepraktisan pengguna soal, maka tingkat kepraktisan soal yang dihasilkan dapat ditentukan berdasarkan tingkat kategori pada tabel kriteria pengkategorian kepraktisan yaitu sebagai berikut Sumber : (Dewi et al., 2019):

Tabel 2 Kriteria Pengkategorian Kepraktisan

\begin{tabular}{|l|l|}
\hline \multicolumn{1}{|c|}{ Interval Skor } & \multicolumn{1}{c|}{ Kategori Kevalidan } \\
\hline $4 \leq \mathrm{Mp} \leq 5$ & Sangat Praktis \\
\hline $3 \leq \mathrm{Mp}<4$ & Praktis \\
\hline $2 \leq \mathrm{Mp}<3$ & Kurang Praktis \\
\hline $1 \leq \mathrm{Mp}<2$ & Tidak Praktis \\
\hline
\end{tabular}


Soal yang didesain dikatakan praktis, jika interval skor rata-rata hasil pengisian lembar kepraktisan atau keterbacaan soal minimal berada pada interval kategori praktis yaitu $3 \leq \bar{m}<4$.

\section{HASIL DAN DISKUSI}

\section{Tahap Preliminary}

Pada tahap ini, diperoleh hasil dari tahap analisis kurikulum bahwa Kurikulum yang digunakan adalah kurikulum 2013 revisi 2017 yang berfokuskan untuk meningkatkan keterkaitan antara kompetensi inti (KI) dan kompetensi dasar (KD) serta mengintegrasikan literasi; keterampilan abad 21 atau 4C (Comumunication, Collaboration, Critical Thinking and Problem Solving, dan Creativity and innovation). Selanjutnya hasil dari tahap analisis materi adalah Materi yang digunakan dalam penelitian ini adalah materi yang paling banyak berhubungan dengan dunia nyata, yaitu materi aritmetika sosial. Aritmetika sosial merupakan salah satu materi yang terdapat pada kurikulum 2013 revisi 2017 dan dipelajari di kelas VII pada saat semester genap. Sebelum siswa mempelajari materi aritmetika sosial, siswa Sebelum siswa mempelajari materi aritmetika sosial, siswa sudah mempelajari materi prasyarat yaitu materi operasi bilangan bulat, bilangan pecahan, bentuk aljabar, dan system persamaan linear satu variabel. sehingga siswa dapat memahami materi aritmetika sosial. Hasil dari tahap analisis siswa diperoleh bahwa siswa yang digunakan sebagai subjek penelitian memiliki rata-rata usia yaitu 13 tahun. Menurut teori Piaget bahwa fase anak yang berada pada usia 11-112 tahun ke atas merupakan fase operasional formal atau anak sudah memikirkan sesuatu yang mungkin terjadi (hipotesis) dan sesuatu bersifat abstrak (Bujuri, 2018).

Selanjutnya hasil analisis soal kemapuan literasi matematis level 3 diperoleh karakteristik dari soal untuk kemampuan literasi matematis level 3 yaitu Soal memuat konsep-konsep matematika untuk kemampuan literasi matematis level 3, Soal sesuai dengan indikator kemapuan literasi matematis level 3, dan Soal sesuai dengan level siswa kelas VII SMP. Pada tahap desain, soal kemampuan literasi matematis level 3 didesain berdasarkan acuan dari hasil analisis kurikulum, analisis materi, analisis siswa, dan analisis soal untuk kemampuan literasi matematis level 3. Setelah soal di desain berdasarkan acuan dari tahap preliminary. Hasil dari tahap ini dinamakan prototype. prototype atau soal yang telah di desain tersebut dimasukkan ke dalam kartu soal.

\section{Tahap Self Evaluation}

Pada tahap ini, diperoleh prototype I sebanyak 14 soal beserta jawabannya yang telah di desain melalui tahap penilaian dan diperbaiki sendiri berdasarkan konten, konstruk, dan bahasa sebelum diberikan kepada validator pada tahap expert review untuk proses validasi.

\section{Tahap Expert Review dan One-to-one}

\section{Expert Review}

Pada tahap ini, prototype I atau soal-soal kemampuan literasi matematis level 3 yang telah didesain ke dalam kartu soal yang berisi kisi-kisi soal dan indikator kemampuan literasi matematis level 3 akan diberikan kepada 2 orang validator yaitu dosen pendidikan matematika Universitas 
Muhammadiyah Bengkulu untuk divalidasi berdasarkan fokus prototype yaitu konten, konstruk, dan bahasa. Proses validasi dilakukan sebanyak 3 kali, yaitu soal-soal harus direvisi berdasarkan komentar/saran dari validator. Pada tahap proses validasi pertama, berdasarkan komentar/saran dari validator 1 dan validator 2 bahwa 14 soal tersebut belum valid dan masih harus direvisi kembali. Selanjutnya soal tersebut direvisi berdasarkan komentar/saran dari validator dan dilakukan kembali proses validasi yang kedua. Adapun hasil dari proses validasi yang kedua, yaitu terdapat 12 soal yang telah dinyatakan valid dan 2 soal yang belum valid ataupun harus diperbaiki kembali berdasarkan komentar/saran dari kedua validator tersebut. Pada tahap proses validasi yang ketiga, didapatkan bahwa 14 soal kemampuan literasi matematis yang telah dinyatakan valid oleh kedua validator berdasarkan konten, konstruk, dan bahasa. Hasil dari tahapan ini dinamakan prototype II. Selanjutnya prototype II akan di ujicobakan pada tahap One-To-One. Adapun komentar/saran dari 2 validator pada proses validasi, yaitu:

Tabel 3 Komentar/Saran Validator pada Validasi ke-1

\begin{tabular}{|c|c|c|c|}
\hline \multirow{2}{*}{$\begin{array}{l}\text { Butir } \\
\text { soal }\end{array}$} & \multicolumn{2}{|c|}{ Komentar/Saran } & \multirow[t]{2}{*}{ Keputusan Revisi } \\
\hline & Validator I & Validator II & \\
\hline 1. & $\begin{array}{l}\text { Penulisan huruf besar } \\
\text { atau kecil serta letak } \\
\text { huruf pada kalimat. }\end{array}$ & Belum sesuai EYD & $\begin{array}{l}\text { Diperbaiki penulisan terhadap } \\
\text { huruf awal yaitu dari kata dafit } \\
\text { menjadi Dafit. }\end{array}$ \\
\hline 2. & Soal valid. & $\begin{array}{l}\text { Tambahkan kata } \\
\text { hubung dan ganti } \\
\text { beberapa kata agar } \\
\text { mudah dipahami } \\
\text { siswa. }\end{array}$ & $\begin{array}{l}\text { Pada soal yang telah disusun } \\
\text { kata yang kurang pas untuk } \\
\text { digunakan diganti dengan kata } \\
\text { yang lebih pas dan mudah } \\
\text { dipahami. }\end{array}$ \\
\hline 3. & Soal valid. & $\begin{array}{l}\text { Konsisten terhadap } \\
\text { penulisan dan } \\
\text { gunakan penulisan } \\
\text { tentang harga yang } \\
\text { mudah dipahami. }\end{array}$ & $\begin{array}{l}\text { Penulisan harga yang } \\
\text { menggunakan dua angka } \\
\text { dibelakang koma dihapuskan dan } \\
\text { diganti dengan simbol tanda } \\
\text { koma beserta tanda kurang. }\end{array}$ \\
\hline 4. & $\begin{array}{l}\text { Pada soal tersebut harus } \\
\text { ada penjelasan merek } \\
\text { sama dan kemudian } \\
\text { pertanyaannya ada kata } \\
\text { paling murah. }\end{array}$ & $\begin{array}{l}\text { Penulisan pada } \\
\text { kalimat dan tabahkan } \\
\text { kata shampo di } \\
\text { pertanyaannya. }\end{array}$ & $\begin{array}{l}\text { Menambahkan penjelasan } \\
\text { tentang merek shampo yang } \\
\text { sama dan memperbaiki bahasa } \\
\text { yang digunakan dalam penulisan } \\
\text { soal serta di bagian pertanyaan } \\
\text { menambahkan kata shampo dan } \\
\text { kata yang paling murah. } \\
\text { Sehingga merek shampo menjadi } \\
\text { "shampo kilau" dan dipertanyaan } \\
\text { menjadi "shampo manakah yang } \\
\text { sebaiknya dibeli pak yus dengan } \\
\text { harga paling murah?". }\end{array}$ \\
\hline
\end{tabular}




\begin{tabular}{|c|c|c|c|}
\hline 5. & $\begin{array}{l}\text { Soal tersebut perlu ada } \\
\text { penjelasan bahwa jaket } \\
\text { yang dibeli merek dan } \\
\text { motif sama dan } \\
\text { penjelasan tentang yang } \\
\text { dibeli itu baju saja, jaket } \\
\text { saja, atau baju dan jaket. }\end{array}$ & $\begin{array}{l}\text { Pada pertanyaan tidak } \\
\text { perlu membuat dua } \\
\text { pilihan pertanyaan, } \\
\text { cukup langsung saja. }\end{array}$ & $\begin{array}{l}\text { Memperbaiki kalimat pada soal } \\
\text { agar penjelasan tentang barang } \\
\text { apa saja yang dibeli lebih jelas } \\
\text { dan mengganti pertanyaan } \\
\text { dengan dua pilihan pertanyaan } \\
\text { menjadi satu pertanyaan atau } \\
\text { langsung. Sehingga informasi } \\
\text { pada soal menjadi jelas yaitu } \\
\text { barang yang dibeli adalah baju } \\
\text { dan jaket, serta pada pertanyaan } \\
\text { hanya menjadi "pilihan manakah } \\
\text { yang akan kalian ambil". }\end{array}$ \\
\hline 6. & $\begin{array}{l}\text { Soal ini belum/ } \\
\text { menggunakan } \\
\text { keputusan secara } \\
\text { berurutan dengan baik } \\
\text { atau kurang sesuai } \\
\text { dengan indikator } \\
\text { kemampuannya. } \\
\end{array}$ & $\begin{array}{l}\text { Hanya hilangkan kata } \\
\text { jelaskan }\end{array}$ & $\begin{array}{l}\text { Memperbaiki soal dan prtanyaan. } \\
\text { Sehingga membuat soal ulang } \\
\text { dengan menabahkan rentetan } \\
\text { informasi di dalam soal. }\end{array}$ \\
\hline 7. & $\begin{array}{l}\text { Sebaiknya } \\
\text { pertanyaannya dijual } \\
\text { dengan harga berapa } \\
\text { supaya ibu Nadien } \\
\text { memperoleh } \\
\text { keuntungan atau tidak } \\
\text { mengalami kerugian. }\end{array}$ & $\begin{array}{l}\text { Pada pertanyaan itu } \\
\text { harus konsisten, jika } \\
\text { menggunakan untung } \\
\text { lawannya rugi atau } \\
\text { keuntungan lawannya } \\
\text { kerugian. }\end{array}$ & $\begin{array}{l}\text { Memperbaiki soal dan prtanyaan, } \\
\text { Sehingga mengubah informasi } \\
\text { yang ada dala soal dan pada } \\
\text { pertanyaan yang di tanyakan } \\
\text { yaitu berapakah harga jual agar } \\
\text { bu Nadien memperoleh } \\
\text { keuntungan. }\end{array}$ \\
\hline 8. & $\begin{array}{l}\text { Sebaiknya } \\
\text { pertanyaannya "Amira } \\
\text { berkeinginan membeli } \\
\text { sebuah spidol dan } \\
\text { beberapa buku tulis, } \\
\text { bukan } 4 \text { buku tulis" } \\
\end{array}$ & $\begin{array}{l}\text { Soal nomor } 8 \text { ialah } \\
\text { pada penulisan soal } \\
\text { itu harus konsisten } \\
\text { dan tidak perlu } \\
\text { menggunakan kata } \\
\text { jelaskan. }\end{array}$ & $\begin{array}{l}\text { Memperbaiki penulisan kalimat } \\
\text { soal dan tidak menabahkan kata } \\
\text { jelaskan. Sehingga mengubah " } 4 \\
\text { buah buku tulis menjadi } \\
\text { beberapa buku tulis". }\end{array}$ \\
\hline 9. & $\begin{array}{l}\text { Soal ditambah } \\
\text { keterangan bahwa 'istri } \\
\text { pak Toni mengusulkan } \\
\text { untuk menjual perkilo } \\
\text { Rp.13.000,- sedangkan } \\
\text { pak Toni akan menjual } \\
\text { perkilo Rp.14.000,- dan } \\
\text { pertanyaannya } \\
\text { sebaiknya pak Toni } \\
\text { menjual jeruk tersebut } \\
\text { apakah menurut usulan } \\
\text { istrinya atau usulan pak } \\
\text { Toni agar mendapat } \\
\text { keuntungan }\end{array}$ & $\begin{array}{l}\text { Penulisan soal itu } \\
\text { harus konsisten dan di } \\
\text { pertanyaan ditambah } \\
\text { kata jika benar, }\end{array}$ & $\begin{array}{l}\text { Memperbaiki penulisan kalimat } \\
\text { soal dan menambahkan } \\
\text { informasi yang disarankan } \\
\text { Sehingga pada soal menabahkan } \\
\text { informasi harga usulan pak toni } \\
\text { Rp.14.000,- dan pada } \\
\text { pertanyaannya menjadi harga } \\
\text { manakah yang akan dipilih untuk } \\
\text { menjual jeruk agar memperoleh } \\
\text { keuntungan. }\end{array}$ \\
\hline 10. & \multirow{4}{*}{$\begin{array}{l}\text { Hanya perbaiki } \\
\text { penulisan kalimat pada } \\
\text { soal dan soal sudah } \\
\text { baik. }\end{array}$} & \multirow{4}{*}{$\begin{array}{l}\text { Hanya perbaiki } \\
\text { penulisan kalimat } \\
\text { pada soal dan soal } \\
\text { sudah baik. }\end{array}$} & \multirow{4}{*}{$\begin{array}{l}\text { Memperbaiki kata dala penulisan } \\
\text { kalimat pada soal }\end{array}$} \\
\hline 11. & & & \\
\hline 12. & & & \\
\hline$\frac{13 .}{14 .}$ & & & \\
\hline
\end{tabular}




\section{One-to-One}

Pada tahap ini, setelah prorotype II telah selesai divalidasi oleh validator dan menghasilkan 14 soal kemampuan literasi matematis level 3 yang valid. Selanjutnya, soal di ujicobakan kepada 6 orang siswa SMP kelas VII yang berada di lingkungan rumah peneliti dan dilakukan dengan cara berhadapan satu lawan satu. Pada tahap uji coba ini, siswa diminta untuk membaca, memahami maksud dan tujuan soal serta memberikan komentar/saran terhadap soal yang diberikan, dan mengisis lembar respon yang diberikan untuk melihat kepraktisan butir soal. Berdasarkan angket/respon siswa, didapatkan sejumlah data rata-rata dari penilaian kepraktisan (keterbacaan) dalam penggunaan soal sebagai berikut:

Tabel 4 Kriteria Kepraktisan Soal Nomor 1 sampai 14

\begin{tabular}{|c|c|c|}
\hline Nomor Soal & Nilai & Kategori Kepraktisan \\
\hline 1 & 3,06 & Praktis \\
\hline 2 & 3,15 & Praktis \\
\hline 3 & 3,33 & Praktis \\
\hline 4 & 3,24 & Praktis \\
\hline 5 & 3,30 & Praktis \\
\hline 6 & 3,15 & Praktis \\
\hline 7 & 3,13 & Praktis \\
\hline 8 & 3,24 & Praktis \\
\hline 9 & 3,26 & Praktis \\
\hline 10 & 3,41 & Praktis \\
\hline 11 & 3,11 & Praktis \\
\hline 12 & 3,56 & Praktis \\
\hline 13 & 3,37 & Praktis \\
\hline 14 & 3,24 & Praktis \\
\hline
\end{tabular}

Berdasarkan tabel di atas, bahwa hasil uji keterbacaan (one-to-one) untuk soal dari nomor 1 hingga 14 dikategorikan praktis dengan nilai rata-rata yang berada pada interval $3 \leq \mathrm{Mp}<4$. Sehingga hasil dari tahap expert review dan one-to-one terdapat sebanyak 14 soal kemampuan literasi matematis level 3 yang sudah valid dan praktis.

Penelitian ini sejalan dengan (Putra et al, 2016) menyatakan bahwa : 1) Prototype perangkat soal yang dikembangkan sudah memenuhi valid dan praktis. Valid secara teoritik dapat dilihat dari hasil penilaian validator, dimana hampir semiua validator menyatakan soal telah baik berdasarkan konten, konstruk dan bahasa. Adapun valid secara kriteria dapat dilihat berdasarkan analisis butir soal dan analisis item butir soal, sedangkan praktis tergambar dari hasil uji coba one-to-one, dan small group dimana semua siswa dapat memahami perangkat soal dengan baik; 2) Soal yang dikembangkan memiliki efek potensial terhadap kemampuam literasi matematis siswa. Hal tersebut terlihat dari hasil field test yang telah dilakukan bahwa semua siswa melibatkan kemampuan literasi dengan menggunakan kemampuan dasar matematika (KDM) dalam menjawab soal.

Soal-soal kemapuan literasi matematis level 3 yang valid dan praktis tersebut tersebut dapat digunakan untuk meningkatkan dan mengukur kemapuan literasi matematis siswa. Hal ini sejalan dengan penelitian dari (Asmara \& Risnanosanti, 2019) menyatakan "bahwa Berdasarkan hasil penelitian 
penerapan model Problem Based Learning dapat meningkatkan kemampuan literasi matematika siswa kelas VII pada kategori sedang pada materi segitiga dan segiempat. Nilai rata-rata sebelum penerapan model PBL yaitu sebesar 43,70 sementara setelah penerapan model PBL nilai rata-rata siswa yaitu sebesar 51,35".

Dalam penelitian ini berdasarkan tahap expert review pada proses validasi yag telah dilakukan oleh 2 orang validator didapatkan bahwa soal kemapuan literasi matematis level 3 materi aritmetika sosial sudah valid berdasarkan konten, konstruk, dan bahasa serta Berdasarkan ujicoba pada tahap oneto-one yang terdiri dari 6 siswa dan sejalan dengan analisis kuantitatif, diperoleh bahwa soal dari nomor 1 hingga 14 telah praktis atau Siswa dapat mengerti maksud dan tujuan dari soal dan soal mudah dibaca serta dapat dipahami, sehingga diperoleh kpraktisan (keterbacaan) soal. hal ini sejalan dengan (Dwi \& Ariani, 2019) bahwa pada tahap expert review berfokus pada kevalidan soal dan menghasilkan prototype II dan pada tahap one-to-one berfokus pada Kepraktisan soal menghasilkan prototype III.

Pada penelitian pengembangan ini, tahapan yang dilakukan untuk uji coba hanya sebatas tahap one-to-one dan tidak dilanjutkan ke tahap small group ataupun field test (uji lapangan) karena keterbatasan waktu yang mana pada saat peneliti ingin melakukan penelitian, di Kota Bengkulu pandemi covid-19 sedang meningkat dan sekolah yang ada di Kota Bengkulu melaksanakan kegiatan pembelajaran melalui daring.

Menurut (Arikunto, 2013) bahwa soal yang berkualitas harus memenuhi persyaratan yaitu validitas, reliabilitas, objektivitas, kepraktisan, dan ekonomis. Soal dapat dikatakan baik dan benar apabila sudah memenuhi kriteria valid dan praktis. Valid dapat diketahui melalui proses validasi dan praktis dapat diketahui apabila soal dapat dibaca dan digunakan oleh seluruh siswa.

\section{Validitas}

Validitas adalah suatu pengukuran dan pengamatan yang menunjukkan tingkat ketepatan dan kecermatan suatu alat ukur dalam melakukan fungsi ukurnya. Menurut (Arikunto, 2018:186) sebuah tes dikatakan memiliki validitas :

1. Aspek Isi

Apabila mengukur tujuan khusus tertentu yang sejajar dengan matri atau isi pelajaran yang diberikan.

2. Aspek Konstruk

Apabila butir-butir soal yang membangun tes tersebut mengukur setiap aspek berpikir.

3. Aspek Bahasa

Apabila butir-butir soal tersebut sesuai dengan EYD

\section{Praktis}

Suatu instrumen dikatakan praktis apabila biaya alat ukur itu mudah dan murah (Muri, 2015). Dalam hal ini kriteria soal essai yang dikatakan praktis adalah soal yang dapat digunakan oleh semua siswa untuk mendapatkan keterbacaan soal. Hal ini sejalan dengan (Hartatiana, 2014) menyatakan bahwa kategori soal itu praktis dan baik sesuia dengan kriteria yang ditetapkan yaitu : 
1. Sesuai dengan alur pikiran siswa, yaitu materinya sesuai dengan yang dipelajari siswa

2. Konteks yang diberikan, siswa mengetahuinya

3. Mudah dibaca dan dipahami

Adapun spesifikasi kriteria produk yang dihasilkan dalam penelitian pengembangan soal essai materi aritmetika sosial yang terstandar berbasis kemampuan literasi matematis level 3 adalah:

1. Soal dikatakan valid apabila semua komentar/saran validator sepakat untuk menyatakan bahwa semua butir soal telah valid berdasarkan konten (sesuai dengan Indikator kemampuan literasi matematis level 3, sesuai dengan materi (aritmetika sosial), dan sesuai dengan tujuan pembelajaran), konstruk (Soal memuat konsep-konsep matematika untuk kemampuan literasi matematis, Gambar, grafik, atau sejenisnya disajikan dengan jelas dan terbaca, dan sesuai dengan level siswa kelas VII SMP), dan bahasa (Sesuai dengan EYD, Penggunaan kata yang mudah dipahami (baku/umum), dan soal tidak mengandung penafsiran ganda.

2. Soal dikatakan praktis apabila siswa telah dapat memahami maksud dari tujuan soal dan berdasarkan skor rata-rata dari hasil pengisian angket/lembar kepraktisan produk dengan minimal berada pada interval kategori praktis yaitu $3 \leq \bar{m}<4$ dan maksimal berada pada interval kategori sangat praktis yaitu $4 \leq \bar{m} \leq 5$.

\section{KESIMPULAN}

Penelitian ini menghasilkan suatu produk yaitu 14 soal essai kemampuan literasi matematis level 3 siswa SMP kelas VII materi aritmetika sosial yang valid dan praktis. Kevalidan soal terlihat dari hasil pada tahap expert review atau hasil penilaian dari validator berdasarkan konten,konstruk, dan bahasa. Kepraktisan soal terlihat dari hasil pada tahap one-to-one atau komentar/saran siswa bahwa siswa dapat mengerti, memahami maksud dan tujuan dari soal, serta dapat terlihat dari analisis kuantitatif yaitu soal dari nomor 1 hingga 14 dikategorikan praktis dengan nilai rata-rata yang berada pada interval $3 \leq \mathrm{Mp}<$ 4.

Berdasarkan hasil penelitian yang dilakukan, maka peneliti memberikan beberapa saran yaitu; 1) pengembangan soal kemampuan literasi matematis level 3 diharapkan dapat membantu siswa dalam melatih diri menyelesaikankan soal kemampuan literasi matematis serta dapat mengukur kemapuan literasi matematis. 2) peneliti selanjutnya diharapkan dapat melanjutkan mengembangkan soal kemampuan literasi matematis level 3 pada pokok bahasan materi lainnya dan diharapkan adanya tindak lanjut untuk penelitian pengembangan soal kemampuan literasi matematis ini ke tahap selanjutnya yaitu small group hingga ke tahap field test (uji coba luas).

\section{REFERENSI}

Abidin, Y., Mulyani, T., \& Yuhansa, H. (2018). Pembelajaran Literasi : Strategi Meningkatkan Kemampuan Literasi Matematika, Sains, Membaca, dan Menulis. Bumi Aksara.

Arfani, L. (2016). Mengurai Hakikat Pendidikan, Belajar Dan Pembelajaran. 11(2), 81-97. 
Arikunto, S. (2013). Dasar-dasar Evaluasi Pendidikan. PT Bumi Aksara.

Arikunto, S. (2018). Dasar-Dasar Evaluasi Pendidikan (edisi 3). Bumi Aksara.

Asmara, A., \& Risnanosanti. (2019). Literasi Matematika Siswa SMP Melalui Model Problem Based Learning. Jurnal Math-UMB. Edu, 53(9), 1689-1699.

Astuti, Y., Bennu, S., \& Paloloang, B. (2018). Identifikasi Kemampuan Literasi Matematika Siswa Kelas VIII SMPN Model Terpadu Madani Pada Materi Aritmatika Sosial. Jurnal Elektronik Pendidikan Matematika Tadulako, 5(3), 356-370.

Bujuri, D. A. (2018). Analisis Perkembangan Kognitif Anak Usia Dasar dan Implikasinya dalam Kegiatan Belajar Mengajar. LITERASI (Jurnal Almaata), 9(1), 37. https://doi.org/10.21927/literasi.2018.9(1).37-50

Dewi, S., Rizal, S., \& Johar, R. (2019). Pengembangan Modul Matematika Diskrit Berbantuan Software wxMaxima. Jurnal Peluang, 7(2), 56-65. https://doi.org/10.24815/jp.v7i2.13747

Dwi, P. T. R., \& Ariani, N. M. (2019). Soal Berpikir Kreatif Matematis Siswa SMP Berkonteks Bengkulu. Jurnal Math-UMB. Edu, 6.

Hamzah, A., \& Muhlisrarini. (2014). Perencanaan dan Strategi Pembelajaran Matematika (1th ed.). Rajawali Pers.

Hartatiana. (2014). Pengembangan Soal Pemecahan Masalah Berbasis Argumen Untuk Siswa Kelas V di SD Negeri 79 Palembang. Jurnal Pendidikan Matematika, 8.

Johar, R. (2012). Domain Soal Pisa Untuk Literasi Matematika. Jurnal Peluang, 1(1), 30.

Kemendikbud. (2014). Peraturan Menteri Pendidikan Dan Kebudayaan Republik Indonesia Nomor 58 Tahun 2014. Jakarta

Maryanti. (2012). Peningkatan Literasi Matematis Siswa Melalui Pendekatan Metacognitive Guidance. Tesis. Universitas Pendidikan Indonesia (UPI). Bandung, 20, 16-39. http://repository.upi.edu/9449/2/t_mtk_1007194_chapter1.pdf

Muri, Y. (2015). Assesmen dan Evaluasi Pendidikan. PT Raja Grafindo Persada.

OECD. (2019). Programme For International Student Assessment (PISA) 2018 Result in Focus- What 15-year-olds know and what they can do with what they know. OECD Publishing. https://doi.org/10.1787/b5fd1b8f-en

Putra, Y. Y., Zulkardi, Z., \& Hartono, Y. (2016). Pengembangan Soal Matematika Model PISA Konten Bilangan untuk Mengetahui Kemampuan Literasi Matematika Siswa. Jurnal Elemen, 2(1), 14. https://doi.org/10.29408/jel.v2i1.175

Ramadianti, W., Syofiana, M., \& Mahyudi. (2018). Pengembangan Soal Matematika Open-Ended Berkonteks Bumi Rafflesia. SJME (Supremum Journal of Mathematics Education), 2(1), 8-16. https://journal.unsika.ac.id/index.php/supremum/article/download/922/913 
Wibowo, A. A., Rif'at, M., \& Yani, A. (2019). Pengembangan Instrumen Tes Untuk Mengukur Kemampuan Literasi Matematis Siswa SMP. Jurnal Pendidikan Dan Pembelajaran Khatulistiwa, 9. https://doi.org/10.24252/auladuna.v5i1a1.2018

Zulkardi. (2006). Formative Evaluation: what, why, when and how. In Oocities (Issue 1993). http://www.oocities.org/zulkardi/books.html 